\title{
Candida for Developing Anti-Diabetics Drugs!
}

Priya R, Aruna $\mathbf{V}^{*}$, Amruthavalli GV, Soundharya R and Gayathri R

Dr. JRK's Research and Pharmaceuticals Pvt. Ltd., No. 18 \& 19 Perumal koil street, Kunrathur, Chennai-600069, India

*Corresponding authors: Aruna V, Dr. JRK's Research and Pharmaceuticals Pvt. Ltd., No. 18 \& 19 Perumal koil street, Kunrathur, Chennai-600069, India, Tel: +91-9566165310; Fax: +91-9566165310; E-mail: aruna_v@jrkresearch.com

Received date: July 17, 2017; Accepted date: August 07, 2017; Published date: August 13, 2017

Copyright: (C) 2017 Priya R, et al. This is an open-access article distributed under the terms of the Creative Commons Attribution License, which permits unrestricted use, distribution, and reproduction in any medium, provided the original author and source are credited.

\begin{abstract}
Usefulness in the blocking of the glucose assimilation pathway of Candida albicans for developing anti-diabetic drug that might potentially down regulate glucose absorption at intestine is explored in the present paper. Colony characteristics and the microscopic distinctions of the organism grown in yeast extract with and without glucose were studied initially. The study findings were then reconciled with the proven efficacy of a herbal preparation and a known drug- Miglitol and thus arrived the above method to be reliable, rapid, reproducible and cost effective for preliminary screening of anti-diabetic drugs. The findings are presented in the paper.
\end{abstract}

Keywords: Glucose; Insulin; Diabetes; Candida albicans; Antidiabetic drug

\section{Introduction}

Diabetes mellitus is considered to be one of the killer diseases of the modern world and the recent statistics indicates that more than $60 \%$ of the global population are either in the border line or affected by diabetes mellitus. Significant proportions of the population are also dying every year directly and or indirectly due to diabetes mellitus. Several factors such as change in diet, untimely and dis-propionate eating, life full of stress and strain etc. are some of the strongly indicated causes of diabetes mellitus [1,2]. Diabetes mellitus itself is an untreatable medical problem and at the same time it is also a precursor and predilection for many complications such as diabetic retinopathy, diabetic neuropathy, diabetic nephropathy, diabetic cardiomyopathy etc. $[3,4,5]$.

The medical consequences of both insulin dependent diabetes mellitus (IDDM) and non-insulin diabetes mellitus (NIDDM) are almost same although the underlying etiopathology and the bio medical genetics may differ [6,7]. Increased blood sugar burden and sugar starved cells due to poor to ill conversion of glucose to glycogen and vice versa progressively affect the well-being and quality of life of the patient.

Although plenty of drugs are available for the management of IDDM and NIDDM, still a 'drug in the form of food' or 'food in the form of drug' preferably from herbal source for the management of the disease is the real need of the hour so that such 'drugs' can be integrated into the lifestyle of the diabetic patients at ease. However identifying and developing such drugs is cumbersome and costly. The above situation warrants a rapid, reliable and cost effective method for screening of anti-diabetic properties of various compounds. The global population is moving aggressively towards plant wealth and plant based preparations to manage various health problems including diabetes mellitus so long as the problems are manageable with such preparations $[8,9]$. In the above circumstances a method for rapid screening of herbs that might possess anti-diabetic effect will have great scientific value and medical significance.
NIKU is a traditional Siddha drug reported to possess multi-various therapeutic benefits such as anti-viral, anti-bacterial, anti-pyretic, analgesic and immune boosting [10-13]. This drug is formulated with 9 herbs with strong support from traditional belief system. Sugar assimilation test is vastly used for differentiating the different species of candida as different species of candida known to exhibit selective and unique sugar assimilation pattern. By using a battery of sugars the species are thus identified based on their ability/inability to assimilate the given sugar $[14,15]$.

In the present study we have made an attempt to exploit blocking the sugar assimilation pattern in $C$. albicans as a tool to understand the possible anti-diabetic potential of herbal extracts. The Candida albicans in minimal essential media post blockage of sugar assimilation known to exhibit both morphological and microscopic distinctiveness which can be compared with the above characteristics of the organism grown in sugar free media.

The present study discusses the anti-diabetic benefit of Dr. JRK's NIKU (Nilavembu Kudineer) in comparison with Miglitol by exploring the sugar assimilation inhibition of Candida albicans as a potential tool. We have used Miglitol because it involves in the reversible inhibition of membrane-bound intestinal a-glucoside hydrolase enzymes $[16,17]$. In simple term Miglitol known to inhibit sugar assimilation. Miglitol is widely used for the treatment of diabetes mellitus because it inhibits certain enzymes that delay the glucose absorption and lowering of postprandial hyperglycemia.

\section{Materials and methods}

\section{Details of the isolates Candida albicans used}

Twenty five clinical isolates of Candida albicans previously identified by the conventional methods [18] were used for the study. Ten days prior to the start of the study all the isolates were re-tested to confirm their sugar assimilation ability is not lost.

\section{Growth study in Yeast extract glucose medium (YEGM)}

The culture suspension adjusted to $104 \mathrm{CFU}$ was inoculated on to a well of $2 \mathrm{~mm}$ diameter in YEGM with and without NIKU and Miglitol 
at $1 \mathrm{mg} / \mathrm{ml}$ concentration. $20 \mathrm{ml}$ of medium was used for preparing plates. Simultaneously the organism was also grown in Sabroud's dextrose agar medium (SDA) as described above. The plates were incubated at $260 \mathrm{C}$ for 2 days.

The growth characteristics of the organism were studied and noted for 2 days and was compared with the growth of the organism in SDA.

\section{Screening of Miglitol, Dr. JRK's NIKU and the individual herbs of NIKU}

Miglitol, NIKU and all the 9 herbs of NIKU were incorporated separately into YEGM at $1 \mathrm{mg} / \mathrm{ml}$ and the organism was inoculated as described above and the plates were incubated at $260 \mathrm{C}$ for 2 days with complete recording of the growth characteristics of the respective isolates grown in media with NIKU or the herbs vis-à-vis the growth of organism in YEGM without these herbs. The entire experiment was done in duplicates.

\section{Study of the microscopic characteristics of Candida albicans} grown in $0.2 \%$ glucose solution with and without NIKU or Miglitol

The Candida strains were grown in glucose solution containing 1 $\mathrm{mg} / \mathrm{ml}$ of Miglitol and NIKU separately and incubated at $260 \mathrm{C}$ for 2 days. The microscopic appearance of the isolates grown in glucose solution with and without NIKU or Miglitol was studied using microscope.

\section{Results}

\section{Growth morphology of Candida albicans in media with and} without sugar

In YEGM (Yeast extract glucose medium) Candida cells show characteristic rich, mucoid colony. The growth pattern of Candida in YEM without glucose exhibited very weak, transparent, button like colony. The growth characteristics of Candida in YEGM media was comparable with that of SDA (Sabroud's dextrose agar) (Figures 1-3 and Table 1).

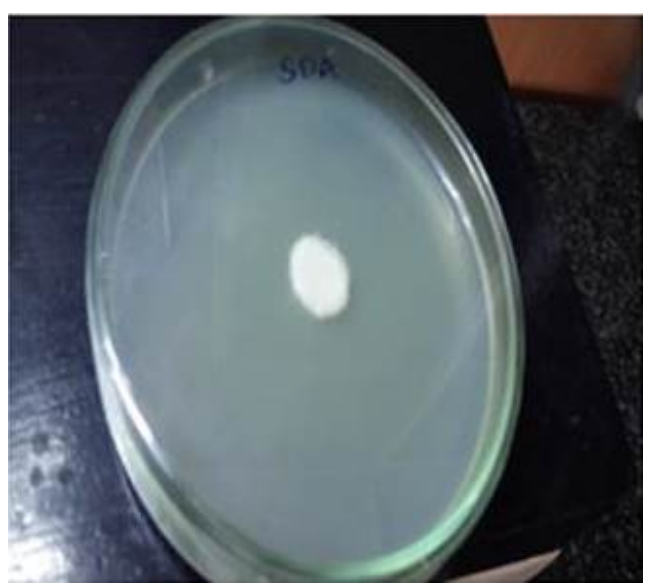

Figure 1: Growth of $C$. albicans in SDA.

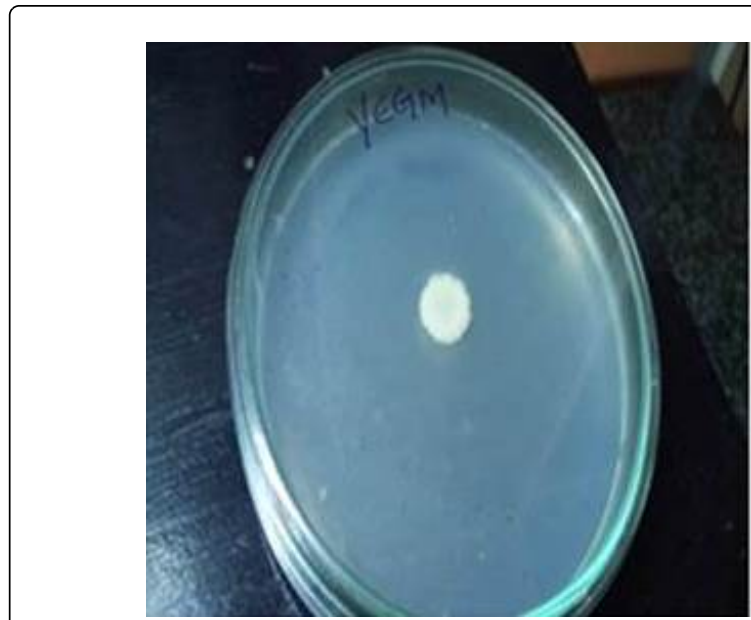

Figure 2: Growth of $C$. albicans in YEGM.

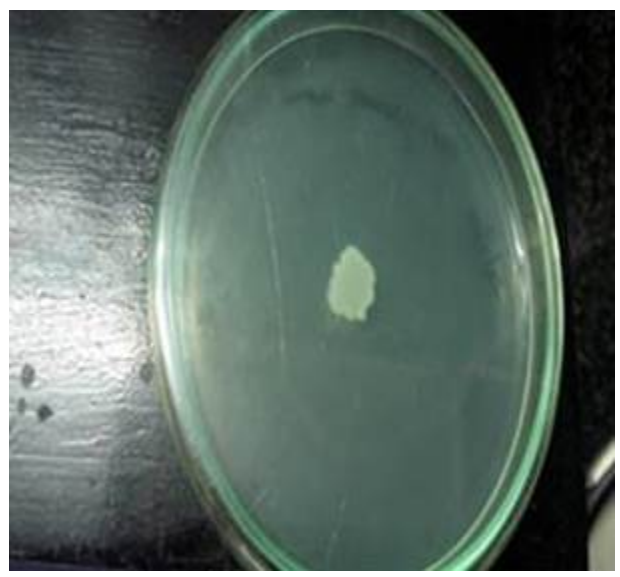

Figure 3: Growth of $C$. albicans in YEM.

\begin{tabular}{|l|l|l|l|l|}
\hline $\begin{array}{l}\text { YEGM } \\
\text { media }\end{array}$ & $\begin{array}{l}\text { YEM without } \\
\text { glucose }\end{array}$ & SDA & $\begin{array}{l}\text { SDA with } \\
\text { NIKU }\end{array}$ & SDA with Miglitol \\
\hline $\begin{array}{l}\text { Rich, } \\
\text { mucoid } \\
\text { colony }\end{array}$ & $\begin{array}{l}\text { Transparent } \\
\text { weak, button } \\
\text { like colony }\end{array}$ & $\begin{array}{l}\text { Rich, } \\
\text { extended } \\
\text { mucoid } \\
\text { colony }\end{array}$ & $\begin{array}{l}\text { Sparse } \\
\text { colony, } \\
\text { appear weak }\end{array}$ & $\begin{array}{l}\text { Impoverished } \\
\text { colony } \\
\text { transparent appearence } \\
\text { appen }\end{array}$ \\
\hline
\end{tabular}

Table 1: Growth pattern of Candida albicans (25 isolates) after 2 days.

$1 \mathrm{mg} / \mathrm{ml}$ of NIKU and Miglitol in YEGM moderately inhibited the growth of Candida albicans. The ingredients such as Cyperus rotundus (Korai Kilangu), Santalum album (Sandhanam), Plectranthus vettiveroides (Vilamicahiver), Vetiveria zizanioides (vettiver) inhibited the growth of Candida albicans significantly.

The ingredients such as Andrographis paniculata (Nilavembu), Zingiber officinale (Sukku), Mollugo cerviana (parpadagam), Trichosanthes cucumerina (Peipudal), Piper nigrum (Milagu) did not affect the growth of Candida albicans (Table 2). 


\begin{tabular}{|l|l|l|}
\hline S.no & Name of the test material & Extent of inhibition of growth of Candida grown in YEGM \\
\hline 1 & Cyperus rotundus (Korai Kilangu) & +++ \\
\hline 2 & Santalum album (Sandhanam) & ++ \\
\hline 3 & Plectranthus vettiveroides (Vilamicahiver) & +++ \\
\hline 4 & Vetiveria zizanioides (vettiver) & +++ \\
\hline 5 & Andrographis paniculata (Nilavembu) & - \\
\hline 6 & Mollugo cerviana (parpadagam) & - \\
\hline 7 & Zingiber officinale (Sukku) & - \\
\hline 8 & Trichosanthes cucumerina (Peipudal) & - \\
\hline 9 & $\begin{array}{l}\text { Piper nigrum (Milagu) } \\
\text { (C. rotundus }+ \text { S. album+ P. vettiveroides }+ \text { V. zizanioides)= Equal proportion of }\end{array}$ & +++ \\
\hline 10 & $\begin{array}{l}\text { NiKU (Equal proportion of 9 herbs) } \\
\text { herbs) }\end{array}$ & ++ \\
\hline 11 & Miglitol & +++ \\
\hline 12 & $\begin{array}{l}+++ \text { indicates inhibition of growth } \\
- \text { indicates no inhibition }\end{array}$ & \\
\hline
\end{tabular}

Table 2: Growth morphology of Candida albicans (25 isolates) in YEGM with $1 \mathrm{mg} / \mathrm{ml}$ of NIKU and its individual ingredients.

Microscopic characteristics of Candida albicans grown in $0.2 \%$ glucose solution with and without Dr. JRK's NIKU and or Miglitol

The microscopic characteristics of Candida cells grown in $0.2 \%$ glucose solution were well grown well matured with abundant blastospore formation. When the Candida cells were grown in $0.2 \%$ solution with $1 \mathrm{mg} / \mathrm{ml}$ concentration of Dr. JRK's NIKU and or Miglitol exhibited highly impoverished state indicating some inhibition of sugar assimilation due to NIKU (Table 3).

\begin{tabular}{|c|c|c|}
\hline $0.2 \%$ glucose solution & $0.2 \%$ glucose solution $+1 \mathrm{mg} / \mathrm{ml}$ Dr. JRK's NIKU & $0.2 \%$ glucose solution $+1 \mathrm{mg} / \mathrm{ml}$ Miglitol \\
\hline $\begin{array}{l}\text { 1. Gorged cells with well spread and rich cytoplasmic } \\
\text { inclusions } \\
\text { 2. Even and uniformly sized cells } \\
\text { 3. Abundant blastopore all around the cells }\end{array}$ & $\begin{array}{l}\text { 1. Miniaturized cells } \\
\text { 2. Condensed cellular inclusions showing impoverished } \\
\text { state of the cells } \\
\text { 3. Increased vacuolar space }\end{array}$ & $\begin{array}{l}\text { 1. Miniaturized sparse cells } \\
\text { 2. Highly Condensed cellular inclusions showing } \\
\text { impoverished state of the cells } \\
\text { 3. Increased vacuolar space }\end{array}$ \\
\hline
\end{tabular}

Table 3: Microscopic characteristics of Candida albicans (25 isolates) grown in $0.2 \%$ glucose broth with and without Dr. JRK's NIKU.

\section{Discussion}

The present study has clearly shown that blocking of sugar assimilation pathway of Candida albicans can be used as an excellent tool to screen various compounds for their anti-diabetic property at large. The sugar assimilation test is vastly used for the identification and characterization of various microbes and more so for various species of Candida [15]. So far no one has ever tried to exploit Candida albicans and their sugar assimilation pattern to screen drugs for diabetes mellitus.

In our present study Candida albicans has exhibited two distinct and incomparable colony characteristics when grown in YEGM media and YEM (without glucose). This confirms that sugar is essential and also it is being utilized by the organism. When we incorporated Miglitol, NIKU and the individual 9 herbs of NIKU separately into YEGM at $1 \mathrm{mg} / \mathrm{ml}$ concentration and the Candida albicans were grown, surprisingly we found significant difference in the growth morphology and growth characteristics of the organism grown in media with different herbs.

NIKU had inhibited the growth of the organism however the growth characteristics of the organism was not absolutely comparable with that of the organism grown in YEM without sugar. However the following herbs such as Cyperus rotundus (Korai Kilangu), Santalum album (Sandhanam) Plectranthus vettiveroides (Vilamicahiver) Vetiveria zizanioides (vettiver) at $1 \mathrm{mg} / \mathrm{ml}$ inhibited the growth of Candida albicans significantly and the growth morphology and other characteristics of the organism grown in YEM without sugar. The findings clearly show that the poor growth of Candida albicans may be due to the inability of the organism to utilize sugar. Our separate experiment on the possible anti-fungal effect of the above herbs on Candida albicans has proved that none of these herbs have any such effect up to a concentration of $1 \%$.

Interestingly the following ingredients in NIKU such as Andrographis paniculata (Nilavembu), Zingiber officinale (Sukku), 
Mollugo cerviana (parpadagam), Trichosanthes cucumerina (Peipudal), Piper nigrum (Milagu) did not affect the growth of Candida albicans possibly these herbs may not have any effects in the utilization of sugar. The growth characteristics of Candida grown in SDA medium incorporated with NIKU /Miglitol was comparable that of the organism grown in YEM without sugar and in YEGM medium incorporated with either NIKU or Miglitol. SDA being sugar rich and protein rich the organism can circumvent nutrient limitations but when NIKU or Miglitol was added such ability the organism did not exhibit exuberantly indicating the strong possibility of glucose assimilation inhibition.

To reconfirm the above possibility we have prepared the extract combination using the herbs that showed high growth inhibition activity of Candida albicans. Surprisingly the extract combination exhibited activity superior than NIKU and the activity of respective individual herbs. The synergy clearly suggests the strong inhibition of sugar absorption by yeast cells by the extract combination.

The microscopic studies of the yeast cells grown in sugar solution with and without NIKU and or Miglitol gave plethoric view on how the sugar absorption inhibition would affect the microscopic characteristics of yeast cells. The yeast cells grown in sugar solution with NIKU exhibited very impoverished state where the cytoplasmic contents were reclusive whereas the organism that was grown in sugar solution without NIKU exhibited normal growth characteristics.

We have not taken just the growth inhibition of the organism in NIKU or the herbs incorporated medium we have also assessed the colony characteristics and microscopic details and compared it in medium with sugar. Therefore the findings clearly suggest the possibility of sugar assimilation inhibition as the principle cause for the above than the anti-fungal effect. Our earlier studies on the effect of NIKU on alpha-amylase and alpha glucosidase (data considered for publication elsewhere) has clearly shown that NIKU possess sugar assimilation inhibition property.

In the light the plenty of collaborative evidences gathered through the present experiment it can be concluded that blocking sugar assimilation of Candida albicans can be used as a reliable, reproducible, cost effective tool for screening compounds for diabetes. However, the likely anti-fungal effects and other phyto-pharmaceutical details also must be considering before drawing any conclusion.

\section{References}

1. NCD Risk Factor Collaboration (NCD-RisC) (2016) Worldwide trends in diabetes since 1980: a pooled analysis of 751 population-based studies with $4^{\star} 4$ million participants. Lancet 387: 1513-1530.
2. International Diabetes Federation (2015) IDF Diabetes Atlas (7thedn) Brussels, Belgium: International Diabetes Federation.

3. Jia G, DeMarco VG, Sowers JR (2016) Insulin resistance and hyperinsulinaemia in diabetic cardiomyopathy. Nat Rev Endocrinol 12: 144-153.

4. Global Burden of Metabolic Risk Factors for Chronic Diseases Collaboration (2014) Cardiovascular disease, chronic kidney disease and diabetes mortality burden of cardio metabolic risk factors from 1980 to 2010: a comparative risk assessment. Lancet Diabetes Endocrino 2: 634-647.

5. Papatheodorou K, Papanas N, Banach M, Papazoglou D, Edmonds M (2016) Complications of Diabetes 2016. J Diabetes Res 2016: 6989453.

6. Zimmerman BR, Service FJ (1998) Management of noninsulindependent diabetes mellitus. Med Clin North Am 72: 1355-1364.

7. W Rodger (1991) Non-insulin-dependent (type II) diabetes mellitus. CMAJ 145: 1571-1581.

8. Modak M, Dixit P, Londhe J, Ghaskadbi S, Devasagayam TP (2007) Indian Herbs and Herbal Drugs Used for the Treatment of Diabetes. J Clin Biochem Nutr 40: 163-173.

9. P Erasto, PO Adebola, DS Grierson, Afolayan AJ (2005) An ethnobotanical study of plants used for the treatment of diabetes in the Eastern Cape Province, South Africa. Afr J Biotechnol 4: 1458-1460.

10. Anbarasu K, Manisenthil KK, Ramachandran S (2011) Anti-pyretic, Anti-inflammatory and Analgesic Properties of Nilavembu Kudineer Choornam: A Classical Preparation Used in the Treatment of Chikungunya Fever. Asian Pac J Trop 4: 819-823.

11. Management of Chikungunya through Ayurveda and Siddha: A Technical Report. Central Council for Research in Ayurveda and Siddha (CCRAS), Department of AYUSH. Ministry of Health and Family Welfare, Government of India.

12. Karthick S, Arunvanan M, Mubarak H, Justus Antony S, Manoharan A, et al. (2013) A Review on Ethno pharmacological Aspects of a Siddha Drug Nilavembu Kudineer. Am J PharmaTech Res 3: 261-274.

13. Christian GJ, Subramanian M, Periyasami D, Manickavasakam K, Gunasekaran P, et al. (2015) Protective Effect of Poly Herbal Siddha Formulation-Nilavembu Kudineer against Common Viral Fevers Including Dengue: A Case Control Approach. Int J Pharma Sci Res 6: 1656-1660.

14. CW Emmons (1977) Medical Mycology. Lea and Febiger, University of California.

15. Hussain Qadri SM, Nichols CW (1978) Tube carbohydrate assimilation method for the rapid identification of clinically significant yeasts. Med Microbiol Immunol 165: 19-27.

16. Sugimoto S, Nakajima H, Kosaka K, Hosoi H (2015) Review: Miglitol has potential as a therapeutic drug against obesity. Nutr Metab (Lond) 12: 51.

17. Campbell LK, Baker DE, Campbell RK (2000) Miglitol: assessment of its role in the treatment of patients with diabetes mellitus. Ann Pharmacother 34: 1291-1301.

18. Rippon JW (1988) Medical mycology: the pathogenic fungi and the pathogenic actinomycetes : 1-797. 